УДК 347

ББК 67.404

M74

Ответственный редактор

Л. А. Аксениук зам. заведующего кафедры гражданского права по научной деятельности РАП, канд. юрид. наук, доцент

Модернизация гражданско-правового регулирования дого-

M74 ворных отношений: Сборник научных статей / Отв. ред. Л. А. Аксенчук. - М.: ЦКБ «Бибком»; РАП, 2014. - 328 с.

\title{
ISBN-online 978-5-905563-31-7
}

В сборнике представлены труды преподавателей Российской академии правосудия и иных высших учебных заведений, судей - материалы Всероссийской научной конференции «Договорное право: теоретические и практические проблемы» (г. Москва, Российская академия правосудия, 9 апреля 2013 года).

Сборник предназначен для научной общественности, преподавателей, аспирантов (соискателей) юридических вузов.

ISBN 978-5-93916-414-6

ISBN-online 978-5-905563-31-7
(C) Коллектив авторов, 2014

(C) Российская академия правосудия, 2014

(c) ЦКБ «Бибком», оформление, 2014 


\section{Содержание}

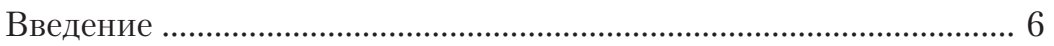

\section{РАЗДЕЛ I \\ Пленарные докиады}

Андреев В.К. Существо корпоративного договора 9

Мельников B.C. Некоторые аспекты модернизации

договорного права

18

Фоков А. П. Общее учение о договоре: теоретические

и практические аспекты 33

Барков А.В. Договорная модель отношений

по устройству детей, оставшихся без попечения родителей:

проблемы теории и правоприменения ……………………………......... 44

Архипов И.В. Объекты в обязательственных правоотношениях .. 55

Кулаков В.В. О системе договоров в гражданском праве ................ 61

Кирпичев А.Е. Понятия предпринимательского договора

и предпринимательского обязательства 67

\section{РАЗДЕЛ ІІ \\ Предпринимательское право}

Андреева Л. В. Правовые проблемы заключения государственных контрактов на проведение научно-исследовательских работ ........ 78 Абросимова Е.А. Роль оптовых продовольственных рынков в формировании договорных связей 91

Белов В.E. К вопросу о формировании института контрактного права 98 Измайлова E. B. Правовая природа договора на установку и эксплуатацию рекламной конструкции в практике Высшего Арбитражного Суда РФ 
Илюшина М.Н. Тенденции модернизации договорного регулирования отношений с участием предпринимателей в проекте ГК РФ

Климан Ю.А. Особенности предмета договора подряда на строительство магистральных нефтепроводов

Ковалькова Е.Ю. Особенности договорного права в сфере размещения заказов

Николаева Т.А. Договор инвестиционного товарищества

как форма предпринимательской деятельности

Овдиенко Е.Б. Особенности правового регулирования

прекращения договорных обязательств зачетом

встречных однородных требований

Поваров Ю.С. Институт оспаривания заключенного

договора (критический анализ новелл проекта ГК РФ)

Пушкина А.В. Договор финансирования под уступку

денежного требования в гражданском праве России

Синдеева И.Ю. Особенности правового сопровождения

исполнения государственного контракта в строительстве

Харитонова Ю.С. О некоторых проблемах квалификации

и правового регулирования договора о слиянии

хозяйственных обществ

\section{РАЗДЕЛ III}

\section{Секция гражданского, семейного и жияищного права}

Аксенчук Л.А. Банковские комиссии в потребительском

кредитовании: нормативно-правовое регулирование

и судебная практика

Арсанукаева М. С. Договор в семейном праве народов

Северного Кавказа

Бондаренко С.А. Современные тенденции регулирования

договорных отношений в сфере образования

Галь И.Г. О рисковом характере обязательства

по оказанию медицинских услуг

Закиров Р.Ю. Публичный договор и договор

присоединения в проекте ГК РФ 228

Крыиула А.А. Договор об отчуждении патента

Коновалов А.И. Договорное оформление деприватизации недвижимого имущества 
Король И.Г. О неустойке за неуплату алиментов по решению суда 245

Мельникова Ю.В. Договорные отношения в сфере использования природных ресурсов 251 Муратова Д.А. Проблемы регулирования исключительных прав супругов на результаты интеллектуальной деятельности 257

Темникова Н.А. Развитие положений о недееспособности и ограниченной дееспособности в российском гражданском праве 261

Толстой P.В. Роль бракоразводных соглашений в правовом регулировании семейных отношений при расторжении брака 267

Филатова У.Б. Модернизация правового регулирования соглашения участников долевой собственности о владении и пользовании общим имуществом 272

Хужин С.М. О возмездности в договорном регулировании медицинской деятельности 279

Черничкина Г.Н. Лицензионный договор: теория и практика его применения 285

Черкашина И.Л. Признание гражданина утратившим право на жилую площадь, занятую на условиях социального найма .. 298 Шаповалова С.А. Об условиях брачного договора с нематериальным содержанием относительно личных прав и обязанностей между супругами 312 Юдин Д. С. Содержание реорганизационного договора 